\title{
Radiation Dose Calculations for a Hypothetical Accident in Xianning Nuclear Power Plant
}

\author{
Bo Cao, ${ }^{1,2}$ Junxiao Zheng, ${ }^{1,2}$ and Yixue Chen ${ }^{1,2}$ \\ ${ }^{1}$ School of Nuclear Science and Engineering, North China Electric Power University, Beijing 102206, China \\ ${ }^{2}$ Beijing Key Laboratory of Passive Nuclear Power Safety and Technology, North China Electric Power University, Beijing 100026, China \\ Correspondence should be addressed to Bo Cao; caobo@ncepu.edu.cn
}

Received 4 June 2016; Revised 30 August 2016; Accepted 4 September 2016

Academic Editor: Turgay Korkut

Copyright (c) 2016 Bo Cao et al. This is an open access article distributed under the Creative Commons Attribution License, which permits unrestricted use, distribution, and reproduction in any medium, provided the original work is properly cited.

\begin{abstract}
Atmospheric dispersion modeling and radiation dose calculations have been performed for a hypothetical AP1000 SGTR accident by HotSpot code 3.03. TEDE, the respiratory time-integrated air concentration, and the ground deposition are calculated for various atmospheric stability classes, Pasquill stability categories A-F with site-specific averaged meteorological conditions. The results indicate that the maximum plume centerline ground deposition value of $1.2 E+2 \mathrm{kBq} / \mathrm{m}^{2}$ occurred at about $1.4 \mathrm{~km}$ and the maximum TEDE value of $1.41 E-05 \mathrm{~Sv}$ occurred at $1.4 \mathrm{~km}$ from the reactor. It is still far below the annual regulatory limits of $1 \mathrm{mSv}$ for the public as set in IAEA Safety Report Series number 115. The released radionuclides might be transported to long distances but will not have any harmful effect on the public.
\end{abstract}

\section{Introduction}

Radiation dose calculation for hypothetical accident or possible radionuclides release from a nuclear facility is very important as far as human health and safety are concerned [1-3]. The radionuclides from accidental releases producing the dose equivalent may be external or internal to the body. The total effective dose equivalent (TEDE) is the sum of the effective dose equivalent (EDE) caused by the external material such as submersion, ground shine, and resuspension and the total committed effective dose equivalent (CEDE) caused by the internal material such as inhalation. The TEDE is the most complete expression of the combined dose from all applicable delivery pathways [4].

The computer code HotSpot is used to calculate the TEDE after the hypothetical accident. The HotSpot which developed by Lawrence Livermore National Laboratory (LLNL) is aimed at providing Healthy Physics for personal and population around the reactor sites. The HotSpot code uses a Gaussian plume model (GPM) to calculate the air concentration and TEDE from nuclides release to the atmosphere [4]. GPM is one of the most widely validated models and its applications have been reported in many areas $[1,2,5-7]$.
The radiological consequences evaluation of design basis accident is one of the important parts of environmental impact assessment and safety analysis of nuclear power plant. Steam Generator Tube Rupture (SGTR) accident is one of the postulated design basis accidents which may occur during the life cycle of the pressurized water reactor nuclear power plant. SGTR accidents have the characteristics of relatively high frequency and serious radiological consequence. Hence, the radioactive source term and radiological consequence of SGTR accident is a problem worthy of study.

In this work, we have performed the radiation dose calculations and radiological consequences of a hypothetical AP1000 SGTR accident by HotSpot code 3.03. TEDE, the respiratory time-integrated air concentration, and the ground deposition are calculated and discussed.

\section{Materials and Method}

2.1. Site-Specific Conditions of the Xianning Nuclear Power Plant. The AP1000 Nuclear Power Plant is located in the Dafan town, Tongshan County, Xianning, Hubei Province, China. Xianning has a temperate continental climate. Meteorological data indicated both North-North-West (NNW) and 
TABLE 1: SGTR accident source term for AP1000.

\begin{tabular}{lc}
\hline Nuclide & Activity released/GBq \\
\hline Kr-85m & $2.10 \times 10^{3}$ \\
Kr-85 & $8.33 \times 10^{3}$ \\
Kr-87 & $9.11 \times 10^{2}$ \\
Kr-88 & $3.49 \times 10^{3}$ \\
Xe-133 & $3.47 \times 10^{5}$ \\
Xe-135 & $9.28 \times 10^{3}$ \\
Xe-138 & $1.77 \times 10^{2}$ \\
I-131 & $1.61 \times 10^{3}$ \\
I-132 & $5.45 \times 10^{3}$ \\
I-133 & $3.45 \times 10^{3}$ \\
I-134 & $2.07 \times 10^{3}$ \\
I-135 & $2.82 \times 10^{3}$ \\
\hline
\end{tabular}

East-North-East (ENE) as the predominant directions, which occurred for $9.3 \%$ and $9.2 \%$. The annual average wind speed on NNW and ENE is reported to be $2.2 \mathrm{~m} / \mathrm{s}$ and $2.1 \mathrm{~m} / \mathrm{s}$, respectively.

Temperature measurements indicate that a minimum temperature of $-5.4^{\circ} \mathrm{C}$ and a maximum temperature of $39.2^{\circ} \mathrm{C}$, the annual average temperature is about $17.3^{\circ} \mathrm{C}$. Measurements of precipitation indicate a mean monthly rainfall for May is about $327.6 \mathrm{~mm}$. For the winter rainy season the rainfall is about $36.3 \mathrm{~mm}$. The annual average precipitation is $1,400 \mathrm{~mm}$. Data are processed from mean daily wind speeds, considering the sun high in the sky. It is observed that the stability class D is predominant with $50.8 \%$ of occurrence, followed by class F with $29.3 \%$ and other classes with $19.9 \%$.

2.2. Source Term and Accidental Release Scenario. The core source term of Xianning NPP is an AP1000 NPP. The source term is used to evaluate radioactive consequences of SGTR accident, which defined in AP1000 Design Control Document [8]. The SGTR accident source term during 0 2 hours for AP1000 is shown in Table 1.

The radionuclide activity released to the atmosphere is immediately picked up by the wind and transported downwind according to the site meteorology. The annual average wind speed at $10 \mathrm{~m}$ is $2.2 \mathrm{~m} / \mathrm{s}$ in the predominant direction of NNW. The default value of receptor height is $1.5 \mathrm{~m}$ and the inversion layer height is $1300 \mathrm{~m}$. The stability class $\mathrm{D}$ is predominant justifying its use in this study. However, other stability classes of $\mathrm{A} \sim \mathrm{F}$ are considered for comparison purposes.

\section{Results and Discussion}

After the hypothetical accident, TEDE, the respiratory timeintegrated air concentration, and the ground deposition are calculated by HotSpot 3.03 as a function of downwind distance is presented in Tables 2 and 3. It can be seen from Table 2 that the respirable time-integrated air concentration, ground surface deposition, ground shine dose rate, and TEDE are very minimal. And the maximum TEDE value of

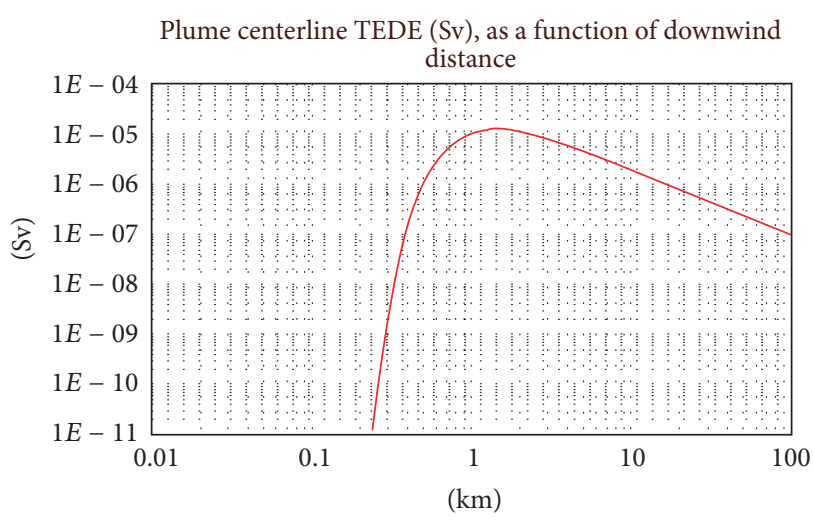

FIGURE 1: TEDE as a function of downwind distance from the NPP site in D class.

$1.41 E-05 \mathrm{~Sv}$ occurred at $1.4 \mathrm{~km}$ at an arrival time of less than ten minutes as presented in Table 2. According to Table 3 and considering the IAEA dose limits set by the IAEA-TECDOC93 [9], it can be observed that there are almost no radiation effects within $0.1 \mathrm{~km}$ in stability of class D. The TEDE rose sharply from $0.1 \mathrm{~km}$ to $2 \mathrm{~km}$ and peaked at $1.41 E-05 \mathrm{~Sv}$ in $1.4 \mathrm{~km}$. Afterwards, the TEDE decreased with the increase of the distance and the rate of decline slowed down gradually until the value has fallen to a very low level. The maximum TEDE value is still far below the annual regulatory limits of $1 \mathrm{mSv}$ for the public as set in IAEA Safety Report Series number 115 [10]. That is to say the released radionuclides might be transported to a long distance but will not have any harmful effect on the public.

The TEDE and plume centerline ground deposition of radionuclides as a function of downwind distance for different stability classes are shown in Figures 1-4. Figure 3 shows that the maximum value of plume centerline ground deposition is $1.2 E+2 \mathrm{kBq} / \mathrm{m}^{2}$ occurred at about $1.4 \mathrm{~km}$ from the reactor. It can be seen from Figures 2 and 4 that the more the unstable meteorological conditions prevail at the site, the higher the value of TEDE and plume centerline ground deposition of radionuclides at a shorter distance will be. Figure 2 shows the decrease of the maximum TEDE values when the meteorological conditions become more stable, and these maximum TEDE values are shifted at longer distances consequently [1]. It is because the dependence of plume rises on downwind distance from the stack as formulated by Briggs [11], and the surface ground deposition radionuclide concentrations are associated with maximum values as noticed by Guldberg $[1,12]$. Figure 4 presents the decrease of plume centerline ground deposition when the meteorological conditions become more stable.

In addition, the TEDE counter plot and plume contour ground deposition distribution for $\mathrm{D}$ stability class in wind speed of $2.2 \mathrm{~m} / \mathrm{s}$ are shown in Figures 5 and 6 , respectively. The plume with three regions marked with dose contours of 5.00E-07, 2.00E-07 Sv, and 1.00E-07 Sv is shown in Figures 5 and 6 . It can be seen from Figure 5 that three boundary contour line areas over these defined doses are exceeded with 52,169 , and $392 \mathrm{~km}^{2}$, respectively, whereas three boundary 
TABLE 2: Downwind distance and other plume parameters at different arrival time intervals.

\begin{tabular}{|c|c|c|c|c|c|}
\hline \multicolumn{2}{|c|}{ Distance $/ \mathrm{km}$ TEDE/Sv } & \multirow{2}{*}{$\begin{array}{l}\text { Respirable time-integrated } \\
\text { air concentration/Bq-sm }\end{array}$} & \multirow{2}{*}{$\begin{array}{c}\begin{array}{c}\text { Ground surface } \\
\text { deposition } / \mathrm{kBqm}^{-2}\end{array} \\
0.00 E+00\end{array}$} & \multirow{2}{*}{$\begin{array}{c}\begin{array}{c}\text { Ground shine dose } \\
\text { rate/Svh }\end{array} \\
0.00 E+00\end{array}$} & \multirow{2}{*}{$\begin{array}{c}\text { Arrival time /h:min } \\
<00: 01\end{array}$} \\
\hline 0.03 & $0.00 E+00$ & & & & \\
\hline 0.1 & $0.00 E+00$ & $0.00 E+00$ & $0.00 E+00$ & $0.00 E+00$ & $<00: 01$ \\
\hline 0.2 & $2.00 E-14$ & $3.50 E+00$ & $6.40 E-08$ & $3.80 E-16$ & 0:01 \\
\hline 0.3 & $2.60 E-09$ & $4.30 E+05$ & $1.10 E-02$ & $6.50 E-11$ & 0:01 \\
\hline 0.4 & $1.70 E-07$ & $2.80 E+07$ & $7.60 E-01$ & $4.60 E-09$ & 0:02 \\
\hline 0.5 & $1.20 E-06$ & $1.90 E+08$ & $5.30 E+00$ & $3.20 E-08$ & 0:02 \\
\hline 0.6 & $3.30 E-06$ & $5.30 E+08$ & $1.50 E+01$ & $8.90 E-08$ & $0: 03$ \\
\hline 0.7 & $5.90 E-06$ & $9.60 E+08$ & $2.70 E+01$ & $1.60 E-07$ & 0:03 \\
\hline 0.8 & $8.40 E-06$ & $1.40 E+09$ & $3.80 E+01$ & $2.30 E-07$ & 0:04 \\
\hline 0.9 & $1.00 E-05$ & $1.70 E+09$ & $4.70 E+01$ & $2.80 E-07$ & 0:05 \\
\hline 1 & $1.20 E-05$ & $1.90 E+09$ & $5.40 E+01$ & $3.20 E-07$ & 0:05 \\
\hline 2 & $1.30 E-05$ & $2.10 E+09$ & $5.60 E+01$ & $3.30 E-07$ & $0: 11$ \\
\hline 4 & $6.80 E-06$ & $1.10 E+09$ & $2.90 E+01$ & $1.70 E-07$ & $0: 22$ \\
\hline 6 & $4.30 E-06$ & $7.40 E+08$ & $1.80 E+01$ & $1.00 E-07$ & $0: 33$ \\
\hline 8 & $3.00 E-06$ & $5.30 E+08$ & $1.20 E+01$ & $6.90 E-08$ & $0: 44$ \\
\hline 10 & $2.30 E-06$ & $4.10 E+08$ & $9.00 E+00$ & $5.00 E-08$ & $0: 56$ \\
\hline 20 & $9.40 E-07$ & $1.80 E+08$ & $3.30 E+00$ & $1.70 E-08$ & $1: 52$ \\
\hline 40 & $3.80 E-07$ & $8.50 E+07$ & $1.10 E+00$ & $4.90 E-09$ & $3: 43$ \\
\hline 60 & $2.20 E-07$ & $5.40 E+07$ & $5.40 E-01$ & $2.20 E-09$ & $5: 35$ \\
\hline 80 & $1.50 E-07$ & $3.90 E+07$ & $3.30 E-01$ & $1.20 E-09$ & $7: 27$ \\
\hline
\end{tabular}

TABLE 3: Human body dose received in different distance from NPP site in D class*.

\begin{tabular}{|c|c|c|c|c|}
\hline \multirow{2}{*}{ Distance/km } & \multirow{2}{*}{ TEDE/Sv } & \multicolumn{3}{|c|}{ Organ dose/Sv } \\
\hline & & Skin & Lung & Thyroid \\
\hline 0.03 & $0.00 E+00$ & $0.00 E+00$ & $0.00 E+00$ & $0.00 E+00$ \\
\hline 0.1 & $0.00 E+00$ & $0.00 E+00$ & $0.00 E+00$ & $0.00 E+00$ \\
\hline 0.2 & $2.00 E-14$ & $3.80 E-14$ & $1.60 E-14$ & $2.50 E-13$ \\
\hline 0.3 & $2.60 E-09$ & $5.40 E-09$ & $2.10 E-09$ & $3.20 E-08$ \\
\hline 0.4 & $1.70 E-07$ & $3.60 E-07$ & $1.40 E-07$ & $2.10 E-06$ \\
\hline 0.5 & $1.20 E-06$ & $2.50 E-06$ & $9.60 E-07$ & $1.40 E-05$ \\
\hline 0.6 & $3.30 E-06$ & $6.90 E-06$ & $2.60 E-06$ & $3.90 E-05$ \\
\hline 0.7 & $5.90 E-06$ & $1.20 E-05$ & $4.70 E-06$ & $7.00 E-05$ \\
\hline 0.8 & $8.40 E-06$ & $1.80 E-05$ & $6.70 E-06$ & $1.00 E-04$ \\
\hline 0.9 & $1.00 E-05$ & $2.20 E-05$ & $8.40 E-06$ & $1.20 E-04$ \\
\hline 1 & $1.20 E-05$ & $2.50 E-05$ & $9.60 E-06$ & $1.40 E-04$ \\
\hline 2 & $1.30 E-05$ & $2.70 E-05$ & $1.00 E-05$ & $1.50 E-04$ \\
\hline 4 & $6.80 E-06$ & $1.40 E-05$ & $5.40 E-06$ & $8.10 E-05$ \\
\hline 6 & $4.30 E-06$ & $9.00 E-06$ & $3.30 E-06$ & $5.10 E-05$ \\
\hline 8 & $3.00 E-06$ & $6.40 E-06$ & $2.30 E-06$ & $3.60 E-05$ \\
\hline 10 & $2.30 E-06$ & $4.80 E-06$ & $1.80 E-06$ & $2.80 E-05$ \\
\hline 20 & $9.40 E-07$ & $2.00 E-06$ & $7.10 E-07$ & $1.20 E-05$ \\
\hline 40 & $3.80 E-07$ & $8.30 E-07$ & $2.80 E-07$ & $4.80 E-06$ \\
\hline 60 & $2.20 E-07$ & $4.90 E-07$ & $1.60 E-07$ & $2.80 E-06$ \\
\hline 80 & $1.50 E-07$ & $3.40 E-07$ & $1.10 E-07$ & $1.90 E-06$ \\
\hline
\end{tabular}

${ }^{*}$ TEDE includes inhalation dose + submersion + ground shine. 


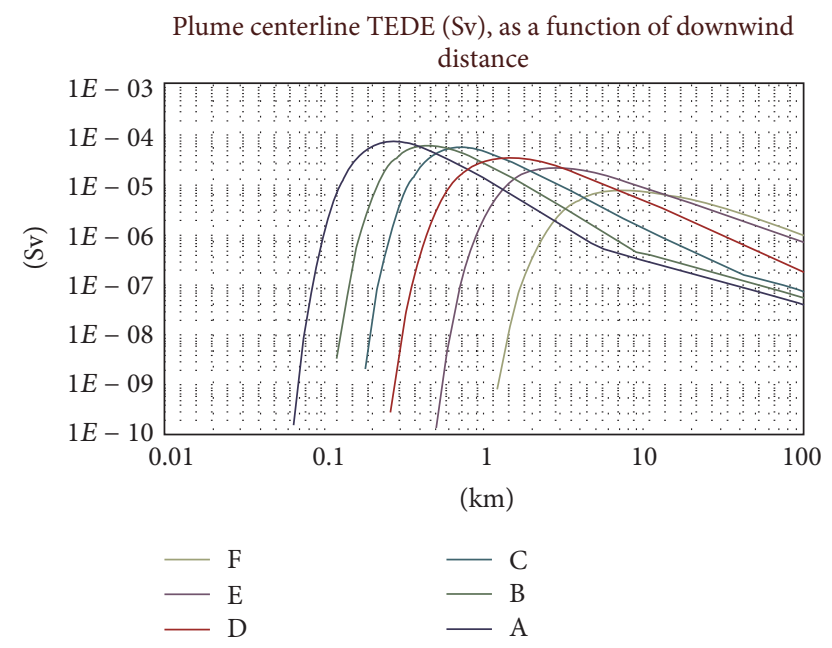

FIGURE 2: TEDE as a function of downwind distance from the NPP site in different stability classes $(\mathrm{A}-\mathrm{F})$.

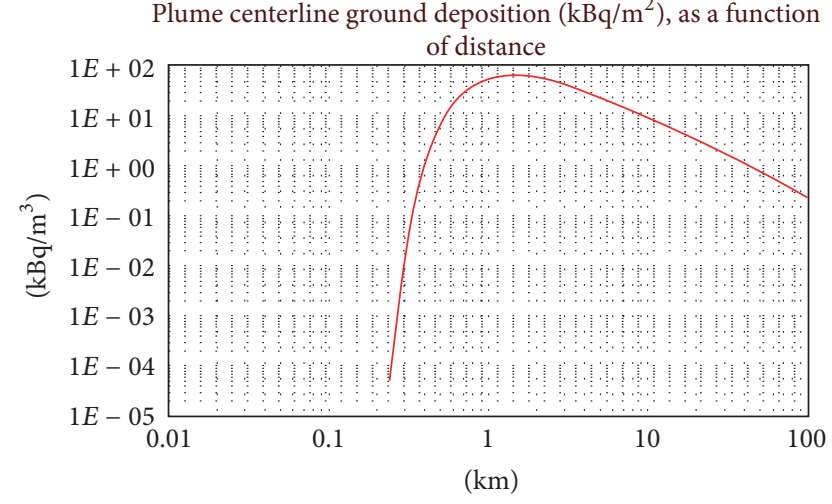

FIGURE 3: Plume centerline ground deposition of radionuclides as a function of downwind distance in D class.

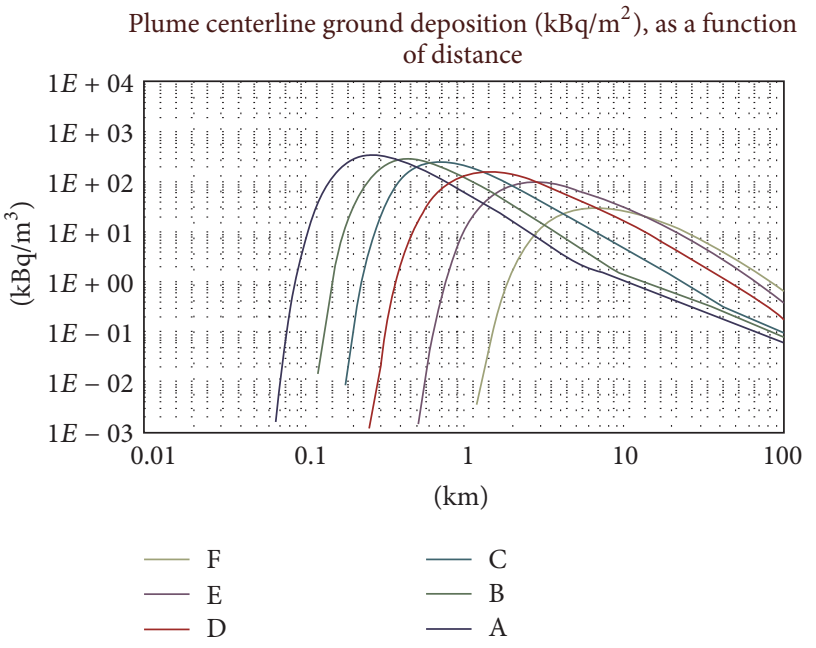

FIGURE 4: Plume centerline ground deposition of radionuclides as a function of downwind distance in different stability classes $(\mathrm{A}-\mathrm{F})$.

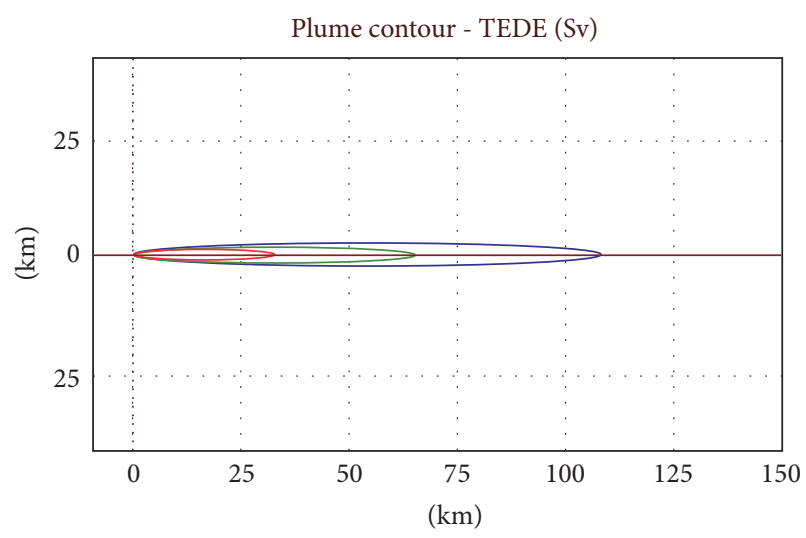

Inner: $5.0 E-07 \mathrm{~Sv}\left(52 \mathrm{~km}^{2}\right)$ Middle: $2.0 E-07 \mathrm{~Sv}\left(169 \mathrm{~km}^{2}\right)$ Outer: $1.0 E-07 \mathrm{~Sv}\left(392 \mathrm{~km}^{2}\right)$ Eff. release height: $75 \mathrm{~m}$ $u(h=10 \mathrm{~m}): 2.20 \mathrm{~m} / \mathrm{s}$ Stability class: D (sample time: $10.00 \mathrm{~min}$ ) Receptor height: $1.5 \mathrm{~m} \quad$ Inversion layer height: $1300 \mathrm{~m}$

Figure 5: TEDE counter plot for D class.

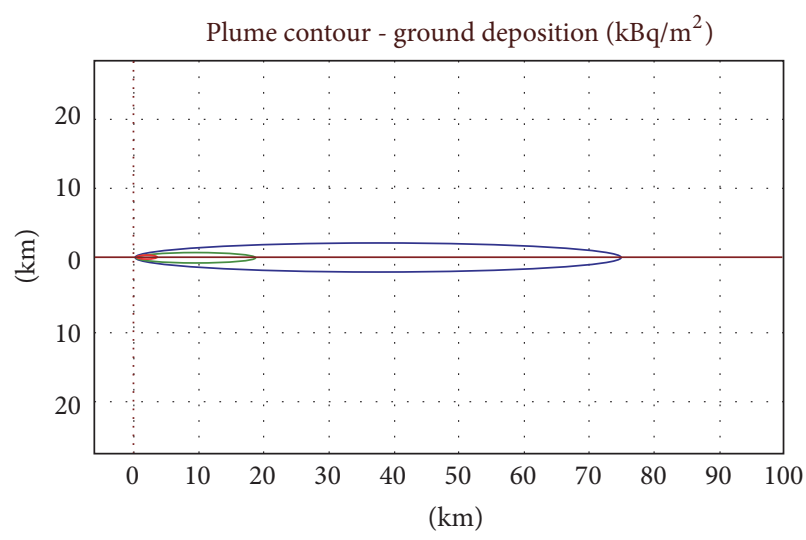

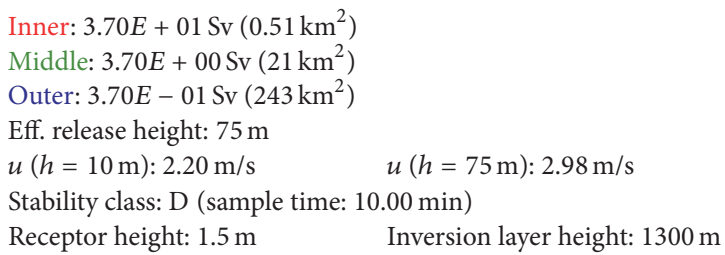

FIGURE 6: Plume contour ground deposition distribution for D class.

contour line areas over these defined doses are exceeded with $0.51,21$, and $243 \mathrm{~km}^{2}$ as shown in Figure 6. According to the results, the calculated TEDE in the different distance from the reactor are considerably lower than the dose limits for personnel and population, which is in agreement with international regulatory document [13-15].

Figure 7 shows the distribution of committed equivalent dose to different organs as a function of downwind distance. CEDE is the value that received by an individual due to remaining at the specified location throughout the entire radioactive material release. This quantity is the sum of the 


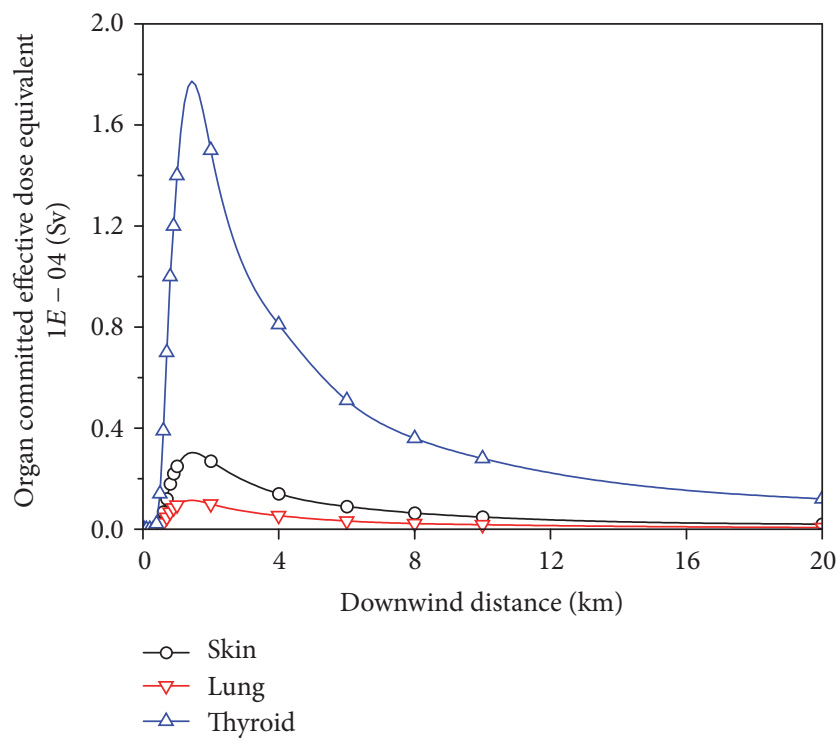

FIGURE 7: Target organ committed equivalent dose as a function of downwind location.

products of the committed dose equivalents for each of the body organs or tissues that are irradiated multiplied by the appropriate weighting factors $\left(W_{T}\right)$ applicable to each of those organs or tissues. It is observed that the highest value of CEDE appears to be the thyroid, followed by the skin and the lung, respectively. The CEDE dose conversion factors (DCF) exploit quality factors or alternately the radiation weighting factors and tissue weighting factors to account for the higher effectiveness of certain forms of radiation and the variable sensitivities of various tissues to cancer induction. The CEDE DCF values should not be used for estimating the probability of acute and early deterministic health effects, as these values specific to the probability of occurrence of stochastic effects in a tissue or organ. The tissue weighting factors used in these DCFs reflect organ sensitivities to cancer induction, not specific deterministic effects. These three organs are more sensitive to radiation compared with others. If any preventative measure is to be taken, their protection would require firstly prevention from inhalation and ingestion immediately after accident.

\section{Conclusions}

In this article, we have performed the radiation dose calculations and radiological consequences of a hypothetical AP1000 SGTR accident by HotSpot code 3.03. After the hypothetical AP1000 SGTR accident, TEDE, the respiratory time-integrated air concentration, and the ground deposition are calculated. The TEDE rises sharply from $0.1 \mathrm{~km}$ to $2 \mathrm{~km}$ and reached peak $1.41 E-05 \mathrm{~Sv}$ at $1.4 \mathrm{~km}$. The TEDE value decreases with the increase of the distance. The maximum TEDE value is far below the annual regulatory limits of $1 \mathrm{mSv}$ for the public as set in IAEA Safety Report Series number 115. The more the unstable meteorological conditions prevail at the site, the higher the value of TEDE and plume centerline ground deposition of radionuclides at a shorter distance will be, which depends on plume rise on downwind distance from the stack. According to the results, the calculated TEDE in the different distance from the reactor are considerably lower than the dose limits for personnel and population, which is in agreement with international regulatory document.

\section{Competing Interests}

The authors declare that there is no conflict of interests regarding the publication of this paper.

\section{Acknowledgments}

The authors are grateful for the support of this research by the National Science and Technology Major Project of the Ministry of Science and Technology of China (2011ZX06004-008), National Natural Science Foundation of China (11605059), and the Fundamental Research Funds for the Central Universities (2015MS13).

\section{References}

[1] J. L. Muswema, E. O. Darko, J. K. Gbadago, and E. K. Boafo, "Atmospheric dispersion modeling and radiological safety analysis for a hypothetical accident of Ghana Research Reactor-1 (GHARR-1)," Annals of Nuclear Energy, vol. 68, pp. 239-246, 2014.

[2] S. S. Raza and M. Iqbal, "Atmospheric dispersion modeling for an accidental release from the Pakistan Research Reactor1 (PARR-1)," Annals of Nuclear Energy, vol. 32, no. 11, pp. 11571166, 2005.

[3] Y. Zhu, J. Guo, C. Nie, and Y. Zhou, "Simulation and dose analysis of a hypothetical accident in Sanmen nuclear power plant," Annals of Nuclear Energy, vol. 65, pp. 207-213, 2014.

[4] S. G. Homann and F. Aluzzi, HotSpot Health Physics Code, Version 3.0, User's Guide, LLNL-SM-636474, National Atmospheric Release Advisory Center, Lawrence Livermore National Laboratory, Livermore, Calif, USA, 2013.

[5] A. Pirouzmand, P. Dehghani, K. Hadad, and M. Nematollahi, "Dose assessment of radionuclides dispersion from Bushehr nuclear power plant stack under normal operation and accident conditions," International Journal of Hydrogen Energy, vol. 40, no. 44, pp. 15198-15205, 2015.

[6] S. A. Birikorang, R. G. Abrefah, R. B. M. Sogbadji, B. J. B. Nyarko, J. J. Fletcher, and E. H. K. Akaho, "Ground deposition assessment of radionuclides following a hypothetical release from Ghana Research Reactor-1 (GHARR-1) using atmospheric dispersion model," Progress in Nuclear Energy, vol. 79, pp. 96103, 2015.

[7] J. L. Muswema, G. B. Ekoko, V. M. Lukanda, J. K.-K. Lobo, E. O. Darko, and E. K. Boafo, "Source term derivation and radiological safety analysis for the TRICO II research reactor in Kinshasa," Nuclear Engineering \& Design, vol. 281, pp. 51-57, 2015.

[8] L. L. C. Westinghouse, Westinghouse AP1000 Design Control Document Rev. 19, Westinghouse Electirc Company LLC, 2011.

[9] IAEA, "Method for developing arrangements for response to a nuclear or radiological emergency," Tech. Rep. IAEATECDOC-953, IAEA, Vienna, Austria, 2003. 
[10] Agency IAE, "International basic safety standards for protection against ionizing radiation and for the safety of radiation sources, Safety Series No.115," Tech. Rep., International Atomic Energy Agency, Vienna, Austria, 1996.

[11] A. G. Briggs, Center N S I. Plume rise. U.S. Atomic Energy Commission, Office of Information Services, 1969.

[12] P. H. Guldberg, "A comparison study of plume rise formulas applied to tall stack data," Journal of Applied Meterology, vol. 14, no. 7, pp. 1402-1405, 1975.

[13] International Commission on Radiological Protection, "1990 Recommendations of the International Commission on Radiological Protection," Annals of the ICRP, vol. 21, no. 1-3, pp. 1-201, 1991.

[14] International Commission on Radiological Protection, "Human respiratory tract model for radiological protection. A report of a Task Group of the International Commission on Radiological Protection," Annals of the ICRP, vol. 24, no. 1-3, pp. 1-482, 1994.

[15] International Commission on Radiological Protection, "Age dependent doses to the members of the public from intake of radionuclides, ICRP 72," Annals of ICRP, vol. 26, no. 1, 1996. 

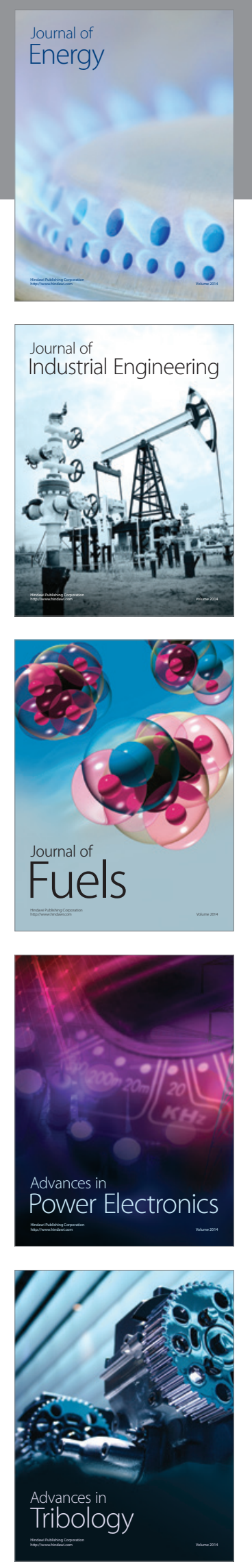
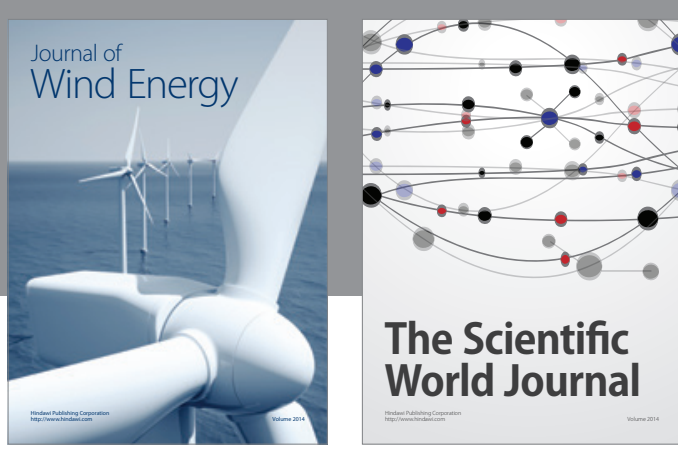

The Scientific World Journal
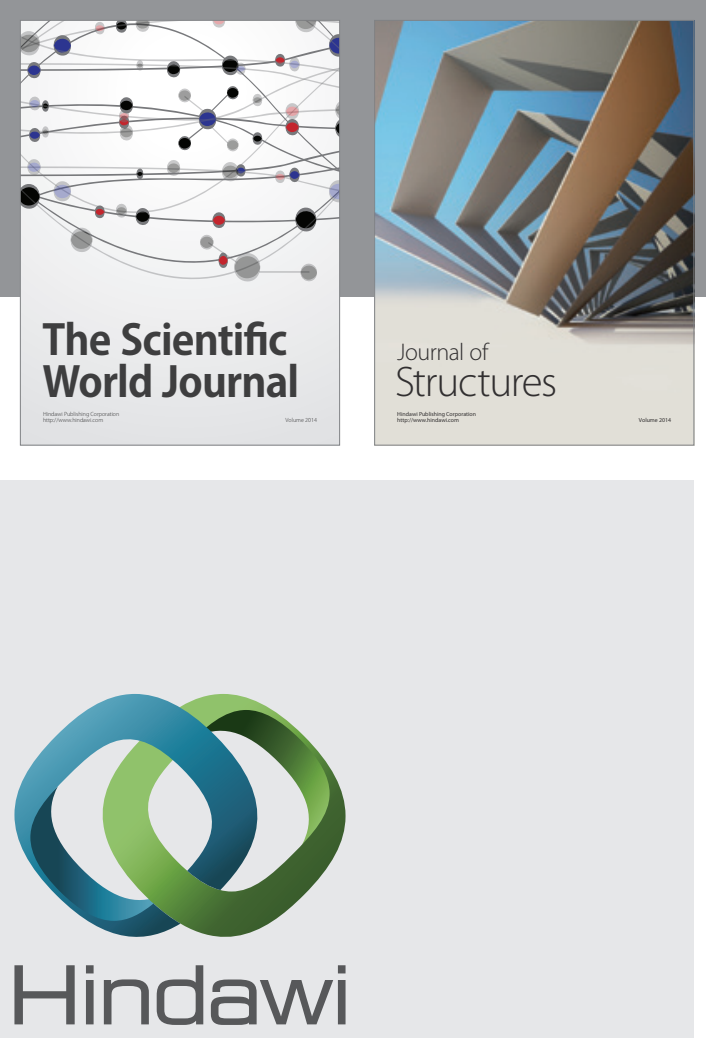

Submit your manuscripts at

http://www.hindawi.com
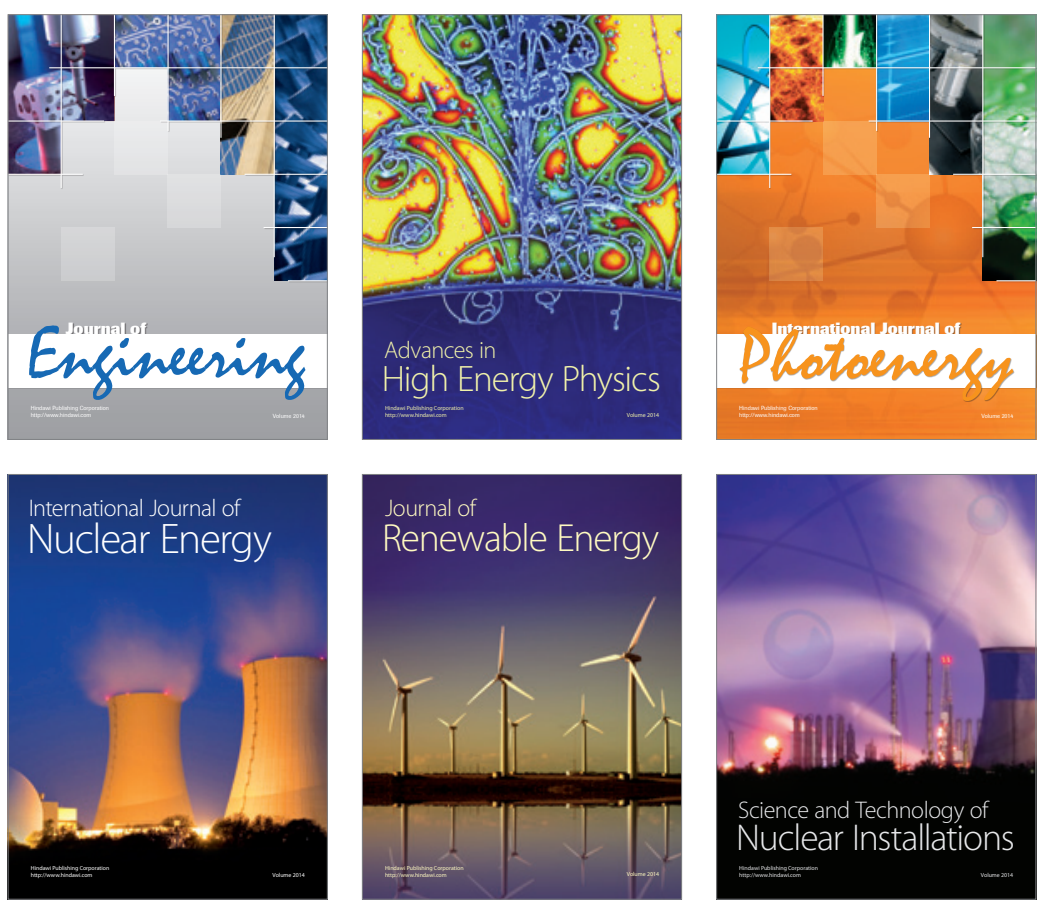
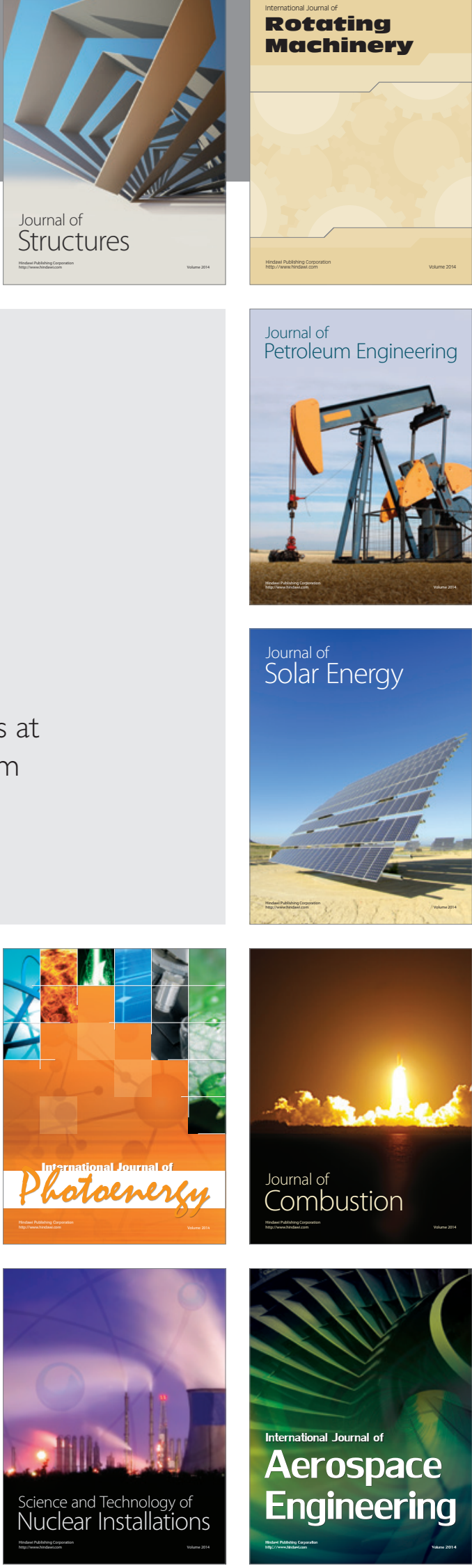